\title{
PENENTUAN PENERIMAAN PEGAWAI MENGGUNAKAN METODE PERBANDINGAN EKSPONENSIAL (MPE)
}

\author{
Tupan Tri Muryono ${ }^{1}$, Irwansyah ${ }^{2}$, Agus Budiyantara ${ }^{3}$ \\ ${ }^{1,2}$ Sistem Informasi, ${ }^{3}$ Teknik Informatika \\ ${ }^{1,2,3}$ Sekolah Tinggi Manajemen Informatika dan Komputer (STMIK) Widuri Jakarta, Indonesia \\ Correspondence email: tupan_tm@yahoo.com
}

Article history: $\quad$ Submission date: Nov 11, 2020 Revised date: Nov 17, $2020 \quad$ Accepted date: Nov 25, 2020

\begin{abstract}
Human resources (HR) plays an important role for the sustainability of higher education therefore xyz universities in conducting the process of selection of employees requires a truly competent employee in their respective fields. The problem in this study is that the selection process of employees is still subjective not based on pure test results and there is no proper method in employee acceptance. The purpose of this research is to get the right staff according to the needs of the college. There are five criteria that will be used in this study are education, work experience, psychotest scores, age, and interview scores. The data collection methods used in this study are interviews, library studies, and observations. The research methods used are the Exponential Comparison Method (MPE) and for the calculation of mpe methods using the python programming language. The result of this study is that mpe method can be applied to determine the admission of employees at xyz college.
\end{abstract}

Keywords: Employee, Python, Exponential Comparison Method.

\begin{abstract}
ABSTRAK
Sumber daya manusia (SDM) berperan penting bagi keberlangsungan perguruaan tinggi oleh sebab itu perguruan tinggi xyz dalam melakukan proses seleksi pegawai membutuhkan pegawai yang benar-benar kompeten pada bidangnya masing masing. Permasalahan dalam penelitian ini adalah pada proses seleksi pegawai masih bersifat subjektif bukan berdasarkan hasil test murni dan belum adanya metode yang tepat dalam penerimaan pegawai. Tujuan dari penelitian ini adalah untuk mendapatkan pegawai yang tepat sesuai dengan kebutuhan dari perguruan tinggi. Ada lima kriteria yang akan digunakan dalam penelitian ini ialah pendidikan, pengalaman kerja, nilai psikotest, usia, dan nilai wawancara. Metode pengumpulan data yang digunakan dalam penelitian ini adalah wawancara, studi pustaka, dan observasi. Metode penelitian yang digunakan ialah Metode Perbandingan Eksponensial (MPE) dan untuk perhitungan metode MPE menggunakan bahasa pemrograman python. Hasil dari penelitian ini adalah metode MPE bisa diterapkan untuk penentuan penerimaan pegawai pada perguruan xyz.
\end{abstract}

Kata Kunci : Pegawai, Python, Metode Perbandingan Eksponensial.

\section{PENDAHULUAN}

Perkembangan teknologi informasi dan komunikasi yang begitu pesat mendorong manusia untuk semakin kreatif, sehingga dapat merubah pola pikir manusia untuk dapat berfikir secara efektif dan efisien agar tidak tertinggal dalam perkembangan dunia teknologi informasi dan komunikasi (Sani et al. 2020).

Sumber daya manusia (SDM) berperan penting bagi keberlangsungan perguruaan tinggi oleh sebab itu perguruan tinggi xyz dalam melakukan proses seleksi pegawai membutuhkan pegawai yang benar-benar kompeten pada bidangnya masing masing. Permasalahan dalam penelitian ini adalah pada proses seleksi pegawai masih bersifat subjektif bukan berdasarkan hasil test murni dan belum adanya metode yang tepat dalam penerimaan pegawai (Galih Surono 2020).

Proses perekrutan Pegawai merupakan tahap yang strategis untuk mengidentifikasi calon yang tepat. Hal yang sama juga diungkap oleh seorang peneliti bahwa proses perekrutan pegawai baru ikut andil dalam 
mengambil kebijakan organisasi (Ade Davy Wiranata et al. 2020).

Tujuan utama dalam proses perekrutan pegawai baru adalah untuk mendapatkan orang yang tepat pada penempatan yang tepat pula sehingga sesuai dengan kondisi dan kebutuhan organisasi atau perusahaan (Rizky dan Ramdhani, 2019).

Penelitian dari Alex Rikki, Murni Marbun, dan Jonson R.Siregar. Dengan judul sistem pendukung keputusan penerimaan karyawan dengan metode saw pada PT. Karya Sahata Medan. Penentuan karyawan selama ini masih dilakukan secara manual, sehingga memakan waktu yang sangat banyak dan tingkat akurasi yang rendah, oleh karena itu maka diperlukan sebuah sistem yang terkomputerisasi, yang dapat mempermudah penentuan karyawan berdasarkan kriteria yang telah ditentukan oleh perusahaan. Metode SAW adalah sebuah teknik yang dibenarkan untuk menentukan nilai terbaik dari beberapa kriteria yang telah ditentukan, oleh karena itu metode ini sangat cocok digunakan untuk menentukan karyawan yang akan diterima oleh PT. Karya Sahata,sehingga karyawan yang akan diterima diambil dari nilai yang tertinggi. Aplikasi ini dirancang dengan layanan pendaftaran dengan memasukkan data pendaftaran penerimaan karyawan baru melalui aplikasi serta pengolahan hasil wawancara, test kepribadian, IPK, test bidang, pengalaman bekerja. Untuk mendapatkan informasi mengenai kriteria karyawan. Hasil dari perancangan sistem ini adalah menghasilkan sistem pendukung keputusan dan informasi hasil seleksi pada proses pengelolaan hasil wawancara, test kepribadian, IPK, test bidang, pengalaman bekerja (Rikki, et al. 2016).

Penelitian dari Rani Irma Handayani dan Ahmad Muzakir dengan judul Sistem Pendukung Keputusan Penerimaan Karyawan Dengan Menggunakan Metode Analytical Hierarchy Process (AHP) Studi Kasus : PT. Virtus Venturama. Latar belakang penelitian ini karena Sulitnya menentukan pelamar mana yang benar-benar berkompeten dan layak menjadi kayawan PT. Virtus Venturama, penempatan karyawan pada departemen yang tersedia kurang efisien. Penelitian ini menggunakan metode Analitytical Hierarchy Process (AHP), sebagai model sistem pendukung keputusan dalam penelitian ini. Dengan menggunakan metode tersebut, hasil akhir yang didapat bahwa Karyawan E (27,6\%), berbanding dengan Karyawan B (27,1\%), Karyawan A $(17,1 \%)$, Karyawan C (10,1\%), Karyawan F (10,1\%), dan Karyawan D $(8,5 \%)$ (Rani Irma Handayani 2018).

Pembaharuan dalam penelitian ini adalah bahasa pemrograman yang menggunakan python dan metode yang digunakan adalah Metode Perbandingan Exponensial (MPE) untuk penentuan penerimaan pegawai.
Sistem Pendukung Keputusan (SPK) merupakan suatu sistem interaktif yang membantu pengambilan sebuah keputusan melalui penggunaan data untuk memecahkan masalah yang sifatnya semi terstruktur dan tidak terstruktur (Turban 2005).

Ada lima kriteria yang akan digunakan dalam penelitian ini ialah : pendidikan, pengalaman kerja, nilai psikotest, usia, dan nilai wawancara. Untuk perhitungan menggunakan bahasa pemrograman python dengan Metode Perbandingan Eksponensial (MPE), yang diharapkan dapat membantu pihak dari perguruan tinggi XYZ dalam pengambilan keputusan dengan cepat, tepat dan bersifat lebih objektif.

\section{METODE PENELITIAN}

\section{Teknik Pengumpulan Data}

Teknik pengumpulan data merupakan langkah yang paling strategis dalam penelitian karena tujuan utama dari penelitian adalah mendapatkan data. Untuk mendapatkan data yang diperlukan. Maka digunakan metode pengumpulan data yang digunakan adalah: (Agus Budiyantara, et al. 2020).

Pertama Melakukan Proses wawancara, dimana wawancara dilakukan secara langsung dengan bagian kepegawaian perguruan tinggi xyz. Kedua melakukan studi pustaka, dimana pengumpulan data dilakukan dengan cara meneliti sejumlah literatur atau referensi yang sekiranya dapat membantu dan mendukung kegiatan penelitian yang dilakukan. Dan yang ketiga melakukan observasi, yaitu dilakukan melalui pengamatan terhadap sejumlah aplikasi sistem pendukung keputusan menggunakan bahasa pemrograman python yang menggunakan Metode Perbandingan Eksponensial (MPE).

\section{Metode Penelitian}

Metode Penelitian yang digunakan yaitu Metode Perbandingan Exponensial (MPE) merupakan salah satu metode pengambilan keputusan yang mengkuantifikasikan pendapat seseorang atau lebih dalam skala tertentu. Pada Prinsipnya ia merupakan metode skoring terhadap pilihan yang ada. Dengan perhitungan secara eksponensial, perbedaan nilai antar kriteria dapat dibedakan tergantung kepada kemampuan orang yang menilai. Langkah-langkah yang perlu dilakukan dalam pemilihan keputusan dengan MPE yaitu :

Pertama Penentuan alternatif keputusan. Kedua Penyusunan Kriteria keputusan yang akan dikaji. Ketiga Penentuan derajat kepentingan relatif setiap kriteria keputusan dengan menggunakan skala konversi tertentu sesuai keinginan pengambil keputusan. 
Dan yang keempat penentuan derajat kepentingan relatif dari setiap alternatif keputusan.

Pemeringkatan nilai yang diperoleh dari setiap alternatif keputusan.

Total Nilai $\left(T N_{i}\right)=\sum_{j=1}^{m}\left(R k_{i j}\right)^{T K K_{j}} \ldots$...(1)

Keterangan :

Tni : Total nilai alternatif ke-i

Rkij : Derajat kepentingan relatif kriteria ke-j pada pilihan keputusan ke-i

TKKj : Derajat kepentingan kriteria keputusan ke-j TKKJ $>0$; bulat

$\mathrm{N}$ : Jumlah pilihan keputusan

M : Jumlah kriteria keputusan

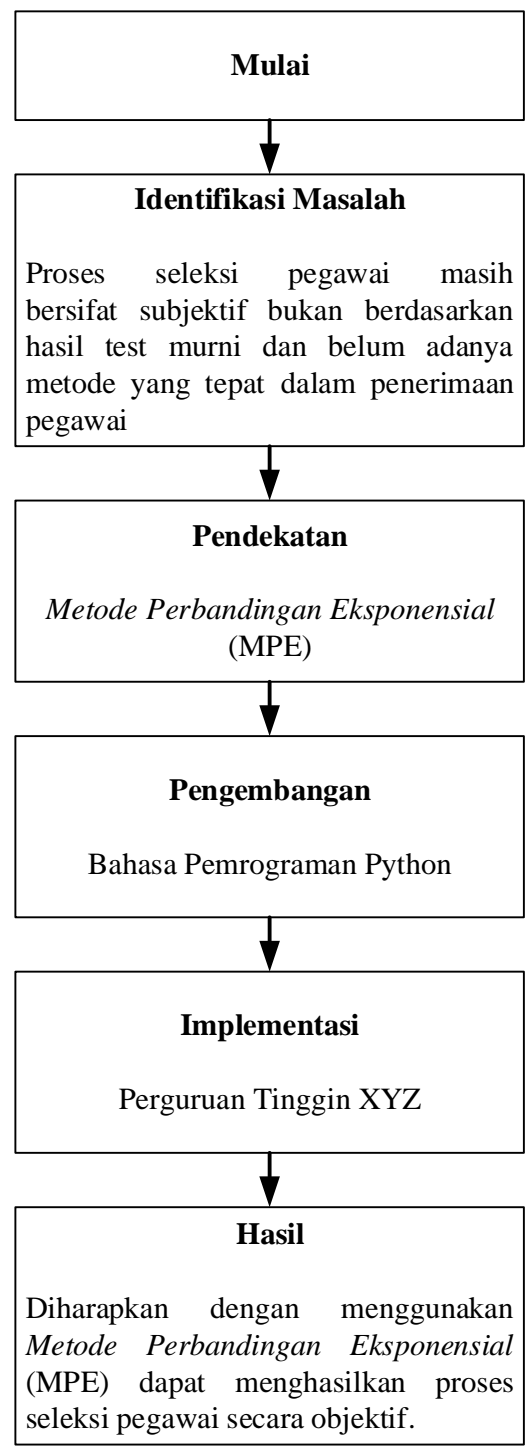

Sumber : (Tupan Tri M, Irwansyah, 2020)

Gambar 1. Langkah-Langkah Penelitian
Pertama identifikasi masalah: permasalahan dalam penelitian ini adalah pada proses seleksi pegawai masih bersifat subjektif bukan berdasarkan hasil test murni dan belum adanya metode yang tepat dalam penerimaan pegawai. Yang kedua pendekatan: pada penelitian ini penulis menggunakan Metode Perbandingan Exponensial. MPE merupakan salah satu metode dari Decision Support System (DSS) yang digunakan untuk menentukan urutan prioritas alternatif keputusan dengan kriteria jamak. Yang ketiga pengembangan: pada penelitian ini penulis menggunakan bahasa pemrograman python. Karena bahasa python merupakan sebuah bahasa tingkat tinggi untuk backend yang bisa menyelesaikan permasalahan seperti machine learning, AI, Dekstop, IoT, dll. Yang keempat implementasi: Hasil dari penelitian ini akan diimplementasikan pada perguruan tinggi xyz. Yang kelima adalah Hasil: hasil dalam penelitian ini dapat menghasilkan proses seleksi pegawai secara objektif.

\section{HASIL DAN PEMBAHASAN}

\section{MetodePerbandingan Eksponensial}

Metode Perbandingan Exponensial (MPE) yang digunakan untuk menentukan penerimaan pegawai yang ada didalam penelitian ini, dengan cara menghitung nilai hasil seleksi pegawai yang akan dipangkatkan dengan masing masing bobot kriteria. Setelah hasil sudah dipangkatkan lalu dijumlahkan. Hasil alternatif yang terbesar akan terpilih sebagai calon pegawai pada perguruan tinggi xyz (Setiawan 2020).

\section{Kriteria dan Pembobotan}

Dibawah ini merupakan penentuan bobot dan kriteria penilaian. Kriteria dan pembobotan yang dijadikan acuan untuk seleksi penerimaan pegawai dapat dilihat pada tabel 1. dibawah ini.

Tabel 1. Kriteria dan Pembobotan

\begin{tabular}{clc}
\hline No & Kriteria & Bobot \\
\hline 1 & Pendidikan & 0,2 \\
2 & Pengalaman Kerja & 0,25 \\
3 & Psikotest & 0,3 \\
4 & Usia & 0,15 \\
5 & Wawancara & 0,1 \\
& Total & 1 \\
\hline & Sumber : (Tupan Tri M, Irwansyah, 2020)
\end{tabular}

Tingkat Kepentingan Dari Setiap Kriteria

Tingka kepentingan dari setiap kriteria mempunyai lima buah pilihan dan nilai pilihan kriteria. Dapat dilihat pada tabel 2. dibawah ini. 
Tabel 2. Tingkat Kepentingan Dari Setiap Kriteria

\begin{tabular}{|c|c|c|}
\hline Kriteria & Pilihan & $\begin{array}{l}\text { Nilai Pilihan } \\
\text { Kriteria }\end{array}$ \\
\hline & SMP & 1 \\
\hline & SMA & 2 \\
\hline \multirow[t]{4}{*}{ Pendidikan } & D3 & 3 \\
\hline & S1 & 4 \\
\hline & $\mathrm{S} 2$ & 5 \\
\hline & $\begin{array}{l}0 \text { Tahun (Fresh } \\
\text { Graduate) }\end{array}$ & 1 \\
\hline Pengalaman & 1-2 Tahun & 2 \\
\hline \multirow[t]{5}{*}{ Kerja } & 3-4 Tahun & 3 \\
\hline & 5-9 Tahun & 4 \\
\hline & $>=10$ Tahun & 5 \\
\hline & $<60$ & 1 \\
\hline & $>=60$ dan $<70$ & 2 \\
\hline \multirow[t]{5}{*}{ Psikotest } & $>=70$ dan $<80$ & 3 \\
\hline & $>=80$ dan $<90$ & 4 \\
\hline & $>=90$ & 5 \\
\hline & $>=40$ & 1 \\
\hline & $>=35$ dan $<40$ & 2 \\
\hline \multirow[t]{5}{*}{ Usia } & $>=30$ dan $<35$ & 3 \\
\hline & $>=25$ dan $<30$ & 4 \\
\hline & $<25$ & 5 \\
\hline & $<60$ & 1 \\
\hline & $>=60$ dan $<70$ & 2 \\
\hline \multirow[t]{3}{*}{ Wawancara } & $>=70$ dan $<80$ & 3 \\
\hline & $>=80$ dan $<90$ & 4 \\
\hline & & 5 \\
\hline
\end{tabular}

Sumber : (Tupan Tri M, Irwansyah, 2020)

\section{Data Alternatif}

Data alternatif yang digunakan dalam penelitian ini yaitu sebanyak lima buah data sampel calon pegawai. Dapat dilihat pada tabel 3. dibawah ini.

Tabel 3. Data Alternatif

\begin{tabular}{cc}
\hline $\begin{array}{c}\text { Kode } \\
\text { Alternatif }\end{array}$ & Nama Calon Pegawai \\
\hline $\mathrm{CP} 1$ & Agung Wahyudi \\
$\mathrm{CP} 2$ & Septi Aulia \\
$\mathrm{CP} 3$ & Oktaviana \\
$\mathrm{CP} 4$ & Noviana \\
$\mathrm{CP} 5$ & Rudi Setyanto \\
\hline
\end{tabular}

Sumber : (Tupan Tri M, Irwansyah, 2020)

\section{Nilai Matrix}

Nilai matrix didapat berdasarkan pilihan dan nilai pilihan kriteria. Dapat dilihat pada tabel 4. dibawah ini.

Tabel 4. Nilai Matrix

\begin{tabular}{cccccc}
\hline Kriteria & $\begin{array}{c}\text { Pendi- } \\
\text { dikan }\end{array}$ & $\begin{array}{c}\text { Pengalaman } \\
\text { Kerja }\end{array}$ & $\begin{array}{c}\text { Psiko- } \\
\text { test }\end{array}$ & Usia & $\begin{array}{c}\text { Wawa- } \\
\text { ncara }\end{array}$ \\
\hline Bobot & 0,2 & 0,25 & 0,3 & 0,15 & 0,1 \\
CP1 & 3 & 2 & 4 & 4 & 2 \\
CP2 & 4 & 5 & 3 & 2 & 4 \\
CP3 & 2 & 2 & 3 & 2 & 5 \\
CP4 & 1 & 4 & 4 & 5 & 1 \\
CP5 & 5 & 2 & 1 & 2 & 3 \\
\hline
\end{tabular}

Sumber : (Tupan Tri M, Irwansyah, 2020)

Pengolahan data matrix yang pangkatkan berikut ini adalah hasil perhitungan yang dibuat penulis dengan menggunakan metode perbandingan eksponensial. Calon pegawai yang memiliki nilai disetiap kriteria akan dipangkankan dengan masing-masing bobot dari setiap kriteria :

a. Total nilai untuk Agung Wahyudi $(\mathrm{CP} 1)=(3)^{0,2}+$ $(2)^{0,25}+(4)^{0,3}+(4)^{0,15}+(2)^{0,1}=6.2535$

b. Total nilai untuk Septi Aulia $(\mathrm{CP} 2)=(4)^{0,2}+(5)^{0,25}+$ $(3)^{0,3}+(2)^{0,15}+(4)^{0,1}=6.4635$

c. Total nilai untuk Oktaviana $(\mathrm{CP} 3)=(2)^{0,2}+(2)^{0,25}+$ $(3)^{0,3}+(2)^{0,15}+(5)^{0,1}=6.0124$

d. Total nilai untuk Noviana $(\mathrm{CP} 4)=(1)^{0,2}+(4)^{0,25}+$ $(4)^{0,3}+(5)^{0,15}+(1)^{0,1}=6.2029$

e. Total nilai untuk Rudi Setyanto $(\mathrm{CP} 5)=(5)^{0,2}+(2)^{0,25}$ $+(1)^{0,3}+(2)^{0,15}+(3)^{0,1}=5.7946$

\section{Hasil Matrix Dipangkatkan}

Matrix dipangkatkan merupakan hasil penjumlahan dari nilai pilihan kriteria dipangkatkan dengan bobot kriteria. Hasil perhitungannya dapat kita lihat pada tabel 5. Dibawah ini.

Tabel 5. Hasil Matrix Dipangkatkan

\begin{tabular}{cccccc}
\hline Kriteria & Pendidikan & $\begin{array}{c}\text { Pengalaman } \\
\text { Kerja }\end{array}$ & Psikotest & Usia & $\begin{array}{c}\text { Wawa- } \\
\text { ncara }\end{array}$ \\
\hline CP1 & 1.2457 & 1.1892 & 1.5157 & 1.2311 & 1.0717 \\
CP2 & 1.3195 & 1.4953 & 1.3903 & 1.1095 & 1.1486 \\
CP3 & 1.1486 & 1.1892 & 1.3903 & 1.1095 & 1.1746 \\
CP4 & 1 & 1.4142 & 1.5157 & 1.2730 & 1 \\
CP4 & 1.3797 & 1.1892 & 1 & 1.1095 & 1.1161 \\
\hline \multicolumn{5}{r}{ Sumber : (Tupan Tri M, Irwansyah, 2020) } \\
\end{tabular}




\section{Hasil Rangking}

Hasil rangking merupakan hasil perhitungan yang telah dilakukan menggunakan metode perbandingan Exponensial. Dapat dilihat pada tabel 6. dibawah ini.

Tabel 6. Hasil Rangking

\begin{tabular}{ccc}
\hline Alternatif & Hasil Perhitungan & Rangking \\
\hline CP1 & 6.2535 & 2 \\
CP2 & 6.4635 & 1 \\
CP3 & 6.0124 & 4 \\
CP4 & 6.2029 & 3 \\
CP4 & 5.7946 & 5 \\
\hline
\end{tabular}

Sumber : (Tupan Tri M, Irwansyah, 2020)

Berdasarkan tabel diatas diperoleh urutan rangking dari pertama sampai kelima yaitu : Septi Aulia dengan nilai 6.4635 menempati rangking pertama, Agung Wahyudi dengan nilai 6.2535 menempati rangking kedua, Noviana dengan nilai 6.2029 menempati rangking ketiga, Oktaviana dengan nilai 6.0124 menempati rangking keempat, dan Rudi Setyanto dengan nilai 5.7946 menempati rangking kelima.

\section{KESIMPULAN}

Berdasarkan penelitian yang telah dilakukan pada kampus xyz, maka dapat diambil kesimpulan sebagai berikut: Metode Perbandingan Eksponensial (MPE) bisa diterapkan untuk penentuan penerimaan pegawai pada perguruan xyz. Dan bahasa yang digunakan untuk menghitung metode Perbandingan Eksponensial (MPE) adalah bahasa pemrograman python. Berdasarkan tabel diatas diperoleh urutan rangking dari pertama sampai kelima yaitu : Septi Aulia dengan nilai 6.4635 menempati rangking pertama, Agung Wahyudi dengan nilai 6.2535 menempati rangking kedua, Noviana dengan nilai 6.2029 menempati rangking ketiga, Oktaviana dengan nilai 6.0124 menempati rangking keempat, dan Rudi Setyanto dengan nilai 5.7946 menempati rangking kelima.

\section{DAFTAR PUSTAKA}

Ade Davy Wiranata and Asrul Sani Irwansyah, Agus Budiyantara. 2020. "Dan Topsis Employee Candidate Selection Using the Saw and Topsis." 3(1):22-35.

Agus Budiyantara, Irwansyah, Egi Prengki, Pandi Ahmad Pratama. 2020. Komparasi Algoritma Decision Tree, Naive Bayes Dan K-Nearest Neighbor Untuk Memprediksi Mahasiswa Lulus Tepat Waktu. Jakarta.

Galih Surono, Nur Nawaningtyas Pusparini. 2020. "Sistem Pendukung Keputusan Penentuan Siswa Teladan Menggunakan Metode Simple Additive Weighting (SAW) Studi Kasus: SD BHAKTI YKKP."

Rani Irma Handayani, Ahmad Muzakir. 2018. "Sistem Pendukung Keputusan Penerimaan Karyawan Dengan Menggunakan Metode Analytical Hierarchy Process (Ahp) Studi Kasus : PT. Virtus Venturama." PILAR Nusa Mandiri 14(1):43-48.

Rikki, Alex, Murni Maebun, and Jonson R. Siregar. 2016. "Sistem Pendukung Keputusan Penerimaan Karyawan Dengan Metode SAW Pada PT. Karya Sahata Medan." Journal of Informatics Pelita Nusantara 1(1):38-46.

Rizky, Ardelia Astriany and Irfan Ramdhani. 2019. "Perancangan Sistem Informasi Perekrutan Karyawan Berbasis Web Menggunakan PHP Dan MySQL DI PT. Ria Indah Mandiri." Jurnal Manajemen Informatika (JAMIKA) 9(1):49-57.

Sani, Asrul, T. K. A. Rahman, Agus Budiyantara, and Rouly Doharma. 2020. "Measurement of Readiness in IT Adoption among SMEs Manufacturing Industry in Jakarta." Journal of Physics: Conference Series 1511(1).

Setiawan, Wawan. 2020. "Pemilihan Guru Terbaik, MPE, Con Implementasi Metode Perbandingan Eksponensial (MPE) Dalam Pemilihan Guru Terbaik Di SMK XYZ." JATISI (Jurnal Teknik Informatika Dan Sistem Informasi) 6(2):212-28.

Tupan Tri M, Irwansyah, Agus Budiyantara. 2020. Penentuan Penerimaan Pegawai Menggunakan Metode Perbandingan Eksponensial (MPE). Jakarta.

Turban. 2005. Decision Support Systems and Intelligent Systems. 1st ed. Yogyakarta: Andi. 
